\title{
Epidemic of Erysiphe platani in urban areas on the example of the Szczecin (NW Poland)
}

\author{
Iwona Adamska
}

West Pomeranian University of Technology in Szczecin, Department of Ecology, Protection and Environmental Development Słowackiego 17, 71-434 Szczecin, Poland

e-mail: Iwona.Adamska@zut.edu.pl

Received: 2 July 2019 / Accepted: 31 October 2019

\begin{abstract}
Investigations a development of infection caused by Erysiphe platani on plane trees (Platanus x hispanica) were conducted in the large city in north-western Poland in the years 2014-2017. Leaf infection as well as the frequency and phenology of the fungus were assessed. The occurrence and biology of E. platani at individual research localities varied depending on the infection time and habitat conditions. A correlation between the presence of Discula platani and the timeline of the occurrence of disease symptoms induced by E. platani was identified.
\end{abstract}

Key words: powdery mildew, plane tree, Platanus, fungi, microscopic fungi.

\section{Introduction}

Plane trees are stately long-lived trees appreciated for their attractive appearance and tolerance to unfavourable urban conditions (Yang et al., 2015). In Europe, their plantings are mostly of human origin. Plane trees can often be found in urban parks and along traffic routes. Damage caused by pests such as the moth Phyllonorycter platani (Staudinger) and by pathogens negatively affects trees' ornamental value. Anthracnose induced by Discula platani and powdery mildew caused by Erysiphe platani (Howe) U. Braun \& S. Takam. are some of the most frequently noted diseases in Europe.

Erysiphe platani chiefly colonizes Platanus digitata, $P$. x hispanica, P. occidentalis and P. orientalis. This taxon has long been noted in North America and has now been found in Australia, New Zealand and Asia (Pastirčáková et al., 2014). It was first recorded in Europe in Italy (Sprenger, 1916; after Pastirčáková et al., 2014). The fungus has since spread and is now observed almost throughout the entire continent (Ranković, 2003; Kirschner, 2011; Scholler et al., 2012; Heluta et al., 2013; Pastirčáková \& Pastirčák, 2006, 2008; Pastirčáková et al., 2014; Ligoxigakis et al., 2015). It was recorded on Ailanthus altissima, a plant of the family Simaroubaceae in the order Sapindales, in Switzerland in 2017 (Beenken, 2017).

As the environment's natural resistance, fungi of the genus Ampelomyces are known to parasitize spores of the anamorphic stage (Pastirčáková et al., 2014). By colonizing hyphae of the mycelium and anamorphic spores of fungi of the order Erysiphales, these hyperparasites inhibit their viability and their ability to colonize new leaf fragments and to form new spores, thus limiting the likelihood of overwintering of these fungi, and are used as an important agent in biological control of pathogens belonging to the order Erysiphales (Sundheim, 1982; Sundheim \& Krekling, 1982; Sztejnberg et al., 1989; Szentiványi \& Kiss, 2003; Kiss et al., 2004; Kiss, 2008; Menge \& Makobe, 2016). 
The aim of the present study was to describe the course and spread of an outbreak of infection caused by E. platani in an urban agglomeration and to identify the pathogen's biology in conditions of anthropopressure.

\section{Material and methods}

Investigations were conducted in the years 2014-2017 in Szczecin (West Pomerania, Poland; 53⒉5 $57^{\prime \prime} \mathrm{N}$, $14^{\circ} 32^{\prime} 53^{\prime \prime}$ E). A total of 80 plane trees Platanus $\mathrm{x}$ hispanica Münchh growing at four research localities were observed. The trees were of various age, with forty trees being approximately 100 years' old (localities A and B) and forty trees being approximately 10 years' old (localities C and D; Table 1). Data on weather conditions are presented in Table 2.

Leaf blades with disease symptoms were investigated. The frequency of microscopic fungi and infection degree were determined twice every month between June and October, and study material (leaf blades with infection symptoms) was collected for examination. Cut and scraped microscopic preparations were performed from diseased leaves in laboratory conditions. The developmental

Table 1. A description of research localities

\begin{tabular}{|c|c|c|c|c|c|}
\hline $\begin{array}{c}\text { Locality } \\
\text { no. }\end{array}$ & Location & Description of locality & $\begin{array}{l}\text { Number } \\
\text { of trees }\end{array}$ & $\begin{array}{c}\text { Tree age } \\
\text { [years] }\end{array}$ & $\begin{array}{c}\text { Height range } \\
{[\mathrm{m}]}\end{array}$ \\
\hline A & $\begin{array}{l}\text { Jasne Błonia } \\
\text { Park }\end{array}$ & $\begin{array}{l}\text { Park locality; tree plantations in two rows in open } \\
\text { space: } 1 \text {. row ca. } 10 \mathrm{~m} \text { away from the road; } 2 \text {. row } \\
\text { ca. } 5 \mathrm{~m} \text { away from the road; light traffic }\end{array}$ & 20 & 100 & $27-30$ \\
\hline B & $\begin{array}{l}\text { Bohaterów } \\
\text { Warszawy } \\
\text { St. }\end{array}$ & $\begin{array}{l}\text { Tree plantations in two rows in a green square } \\
\text { acting as a central reservation between two lanes; } \\
\text { locality ca. } 2 \mathrm{~m} \text { away from the road; heavy traffic }\end{array}$ & 20 & 100 & $26-28$ \\
\hline $\mathrm{C}$ & Belgijska St. & $\begin{array}{l}\text { Trees in a green plantation, ca. } 5 \mathrm{~m} \text { away from the } \\
\text { road; light traffic; very close proximity to a busy } \\
\text { road }\end{array}$ & 20 & 10 & $4-7$ \\
\hline $\mathrm{D}$ & $\begin{array}{l}\text { Duńska - } \\
\text { Złotowska } \\
\text { St. }\end{array}$ & $\begin{array}{l}\text { Trees in a green plantation, ca. } 3 \mathrm{~m} \text { away from the } \\
\text { road; heavy traffic }\end{array}$ & 20 & 10 & $4-8$ \\
\hline
\end{tabular}

Table 2. Weather conditions in Szczecin during the research period

\begin{tabular}{|c|c|c|c|c|c|c|c|c|}
\hline \multicolumn{9}{|c|}{ Average monthly temperature $\left({ }^{\circ} \mathrm{C}\right)$} \\
\hline & III & IV & $\mathrm{V}$ & VI & VII & VIII & IX & $X$ \\
\hline 2014 & 6.8 & 10.8 & 13.4 & 16.3 & 21.3 & 17.5 & 15.4 & 11.8 \\
\hline 2015 & 5.7 & 8.7 & 12.5 & 15.6 & 18.6 & 21.1 & 14.1 & 8.5 \\
\hline 2016 & 4.3 & 8.8 & 15.7 & 18.5 & 19.0 & 17.8 & 16.8 & 8.6 \\
\hline 2017 & 6.7 & 7.4 & 14.1 & 17.2 & 17.7 & 18.2 & 13.6 & 11.2 \\
\hline \multicolumn{9}{|c|}{ Average monthly humidity (\%) } \\
\hline & III & IV & V & VI & VII & VIII & IX & $\mathrm{X}$ \\
\hline 2014 & 76.8 & 73.2 & 72.9 & 72.0 & 70.9 & 74.1 & 81.5 & 87.7 \\
\hline 2015 & 72.8 & 68.4 & 69.4 & 71.1 & 70.4 & 65.4 & 79.4 & 81.0 \\
\hline 2016 & 80.6 & 67.5 & 64.7 & 71.2 & 73.8 & 75.6 & 75.3 & 88.8 \\
\hline 2017 & 73.6 & 73.8 & 70.9 & 74.5 & 79.4 & 76.5 & 82.1 & 85.6 \\
\hline
\end{tabular}


stage of the fungi was identified and morphological properties of the structures formed by the species were described. Only fully mature structures were measured for teleomorphs.

Ten trees at localities A-D were selected to examine the biology of E. platani. Ten randomly selected leaves with symptoms of the true powdery mildew were collected from the trees in the fourth week of October. Three $1 \mathrm{~cm}^{2}$ sites were marked on each such leaf in the laboratory and teleomorphs were counted at each site. These fruitbodies were then plated onto a drop of lactic acid and the development stage was identified. Three stages in a teleomorph's development were distinguished (Sucharzewska et al., 2012): I - young teleomorphs, with unpigmented (hyaline or straw-coloured) walls, without appendages; II - teleomorphs with light-brown walls, with partly developed appendages; III - fully developed teleomorphs: with brown walls and fully developed appendages. Fruitbodies were also checked for the presence of Ampelomyces spp. spores by pressing them until the walls surrounding them burst to release the content which was then examined.

The mycelium colonized by hyperparasitic Ampelomyces spp. were examined to test the ability of anamorphic spores of E. platani to germinate. Spores were plated onto a drop of distilled water on a microscopic slide. The ability to germinate was assessed every 30 minutes. Water in the drop was systematically topped up. E. platani spores sampled from mycelium fragments free from the hyperparasite were used as control.

The occurrence frequency of the fungus was determined on a percentage scale. The frequency was accepted to be $100 \%$ when symptoms of the true powdery mildew were noted on all the trees studied at a locality. In order to estimate the degree of leaf infection by Erysiphe platani ten leaf blades were randomly selected during each observation and the surface affected by pathological changes (white powdery coating) was calculated. Values for each locality were averaged.

A one-way variance analysis of abundance of fruitbodies in individual infection years was performed. Mean values obtained were compared using Scheffe's test (significance level 0.05).

\section{Results and discussion}

\subsection{Frequencies and infection degrees of leaves by $E$. platani}

True powdery mildew and anthracnose of plane trees were observed at all the research localities (Fig. 1).

E. platani was first observed in the city in 2014 (present study). Different frequencies and infection degrees of leaves by E. platani depending on the leaf age, tree age and environmental conditions at a habitat were noted.

The infection was always more severe on newer leaves than on older ones. Leaf blades only developing from leaf buds often dried up when attacked by the pathogen. Older, fully developed leaves exhibited few symptoms of the true powdery mildew. Disease changes affecting the entire surface of older leaves were observed only at locality B. Variations in the colonization degree between newer and older leaves are related to the changes in the leaf structure of plane trees while aging in response to meteorological conditions. Fully developed leaf blades are leathery, with an almost glabrous skin in comparison to new leaves having more delicate skin with tomentose trichomes (Carpenter et al., 2005). While trichomes are considered to be important for plant protection from radiation, pests and diseases (Xiao et al., 2017), trichomes covering new leaves may favour the occurrence of pathogens, including $\mathrm{E}$. platani, enabling spores to attach to the leaf surface (Calo et al., 2006; Salazar et al., 2007; Kirschner, 2011). Longer by ca. $20 \%$ than conidiophores of E. platani (Yarwood \& Gardner, 1970 after Kirschner, 2011), trichomes can provide better conditions for the formation of anamorphic spores and can increase disease symptoms within a leaf blade. Leaves covered with dense trichomes retain moisture for longer than glabrous leaves which encourages the germination of pathogen spores (Lindow \& Brandl, 2003; Calo et al., 2006). The type of leaf trichomes also impact drop size upon fall and dispersal of rain drops (Geagea et al., 2000; Levia et al., 2017), which affects the spread of fungal spores.

A better developed, thicker skin of older leaves acts as a barrier to E. platani hyphae. Disease changes are slower to spread on such leaves than on new ones. While disease symptoms expanded more quickly on newer leaves than on older ones in the present study, a strong infection of new blades was observed only in mid-July. The infection degree of new leaf blades developing from leaf buds in earlier months (May-June) was low. This suggests that other environmental factors, most likely meteorological conditions, have a strong influence on the disease course.

E. platani adversely affected the development of young trees. Leaves of young trees (localities C and D) were infected by $E$. platani more severely than those of older trees. Moreover, leaf buds and the newest leaves very often died back which inhibited plant growth and may have determined the crown form. On the other hand, the fungus did not affect the development condition of older trees, even in cases of severe leaf infection and high frequency (locality B). Changes in plant resistance to pathogens over time have been evidenced in the literature and are related to development phases reached by the tree (Develey-Rivière \& Galiana, 2007; Machowicz-Stefaniak \& Zalewska, 2009; Bonde et al., 2012). Plant pathogens, 
including parasitic fungi, induce changes at the cellular and systemic levels when colonizing a plant. This is particularly evident in young plants that are at a period of intensive growth, leading to changes in the growth rate and plant habit.

The infection degree and the frequency of trees belonging to one age group (older trees) varied depending on the locality (Fig. 1). Low tolerance of plane trees at locality B as compared to that of trees at locality A was correlated with different habitat conditions at both sites. Traffic is considerably lighter in the vicinity of locality A than locality B. Plants at locality A (a park site) have better access to water and mineral nutrients that those at locality B (near a busy road). Alien substances penetrating the soil environment at locality B due to traffic incidents, de-icing and snow clearing can also play a considerable role (Czerniawska-Kusza et al., 2004; Dmuchowski et al., 2013, 2014). Urban conditions exert strong influence on tree development and thus on their resistance to pathogens and pests (Dineva, 2004; Oleksyn et al., 2007; Mimet et al., 2009; Grote et al., 2016). This is also observed for plane trees considered to be tolerant to humanderived pollution (Santamour \& McArdle, 1986; Dineva, 2004). Urban conditions also determine fungal biology, which can be exhibited by changes in their pathogenicity (Dynowska, 1994, 1996; Dynowska \& Sucharzewska, 2005; Sucharzewska \& Dynowska, 2005; Newbound et al., 2010).

Leaf infection rate and frequency of E. platani decreased at all the localities in the years 2016-2017. This may have been caused by the influence of meteorological conditions on pathogen biology, environmental resistance related to, among others, the presence of hyperparasites, and the development of resistance of the hosts colonized. As part of their evolution, plants may have developed many defence mechanisms helping them to avoid an infection or to control pathogens at the initial stage of the disease (Boyd et al., 2013; Singh \& Chandrawat, 2017; Surendra \& Cuperlovic-Culf, 2017; Xiao et al., 2017).

\subsection{Phenology}

The occurrence of E. platani was noted at each research locality (Fig. 2). The occurrence of the anamorphic stage Oidium spp. was related to meteorological conditions. In 2014, it was observed at the beginning of August at the majority of the localities and in the second half of June at locality B. In 2015, despite climatic conditions favouring the development of E. platani, the fungus occurred on the plants later than in 2014: the anamorphic stage was noted at the end of July (locality B) and at the end of August (localities A, C and D; Table 3). This late occurrence can be attributed to the simultaneous occurrence of the causal agent of plane anthracnose, Discula platani, on the plant. Changes caused by D. platani increased considerably in the autumn 2014, causing dieback of the youngest shoots of the host, which negatively influenced the overwintering of E. platani. This suggests that pruning out the newest twig tips in plane trees recommended for D. pla-

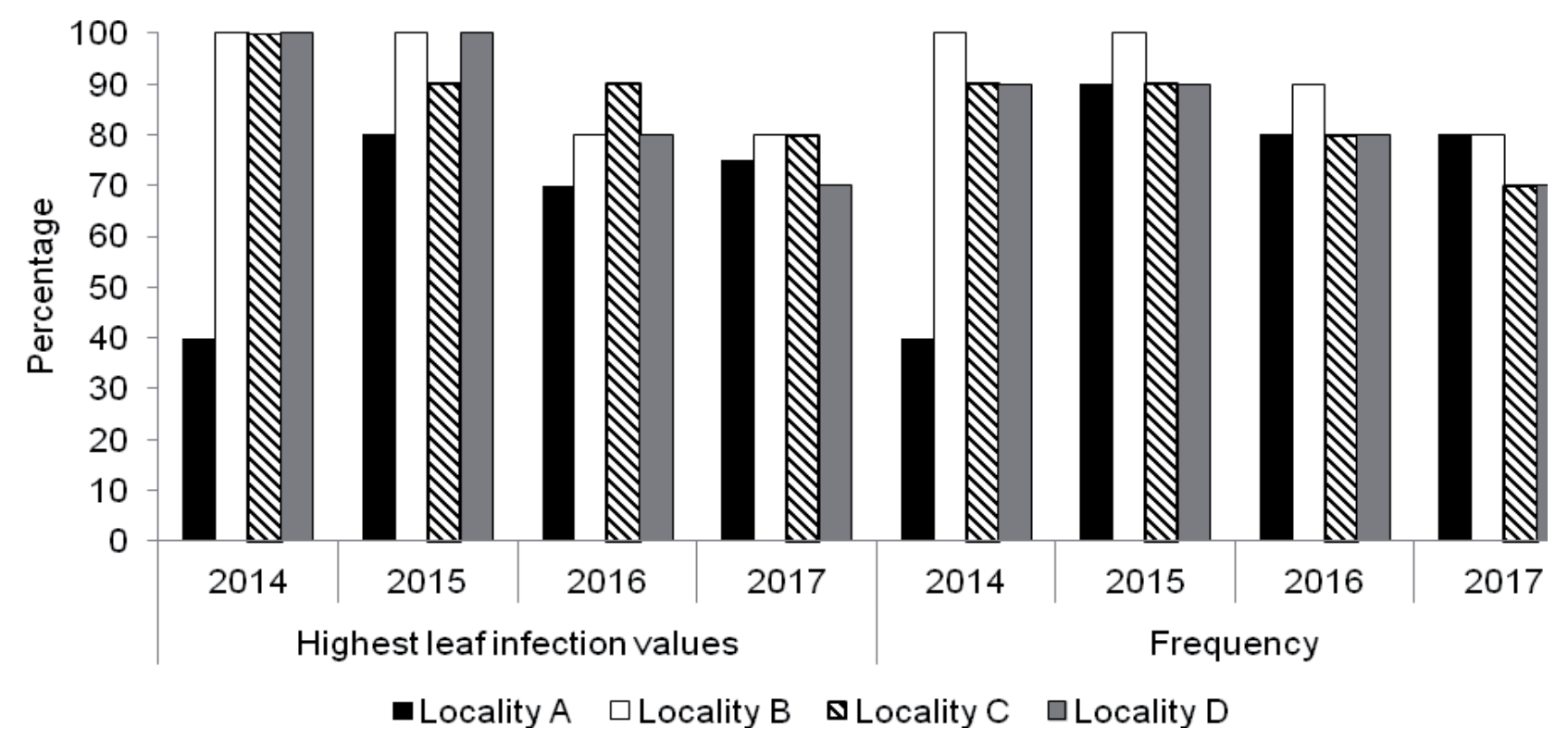

Figure 1. The occurrence dynamics of E. platani in the years 2014-2017 
tani control could also inhibit the occurrence of $E$. platani. The anamorphic stage was found ca. mid-June in the years 2016-17.

The development timeline of the teleomorphic stage varied in the first year of infection by E. platani. In 2014, teleomorphs were observed in October at localities A, C and $\mathrm{D}$ while they were noted as early as at the end of August at locality B (Table 3). Only slight differences were noted in the subsequent years (2015-2017): fruitbodies formed two weeks earlier at locality B than at the other localities while teleomorphs were observed only at the beginning of October at locality A. A more severe development of the disease and increased symptoms in the first years of an outbreak have been observed for other pathogens (Zimmermannová-Pastirčáková et al., 2002; McEvoy et al., 2016).

In the first year of infection, young, undeveloped fruitbodies had the highest percentage contribution while fully developed fruitbodies were the least numerous group (Fig. 3). The highest abundance was recorded for maturing and mature in the subsequent years (Fig. 4; Table 4 and 5).

Differences in the infection degree of the host, fungus frequency and biology (during the development of teleomorphic fruitbodies) may on the one hand suggest a different time of primary infection of the plant and a shift in the range of E. platani in the city. On the other hand, they may suggest the influence of habitat conditions on its development. Comprehensive research on the spread of E. platani and the time of occurrence of individual developmental stages of the fungus was conducted in Germany (Scholler et al., 2012).

Varied traffic loads at the localities also affected the development timeline of teleomorphic fruitbodies. E. platani exhibited higher frequency and leaf infection and formed resting stages more quickly at localities B-D where the traffic was heavy than at locality A where the amount of exhaust fumes was lower. Some microscopic fungi develop teleomorphic stages earlier which allows them to survive unfavourable conditions, adjust to changing environmental conditions and to modify the morphology of some of their structures (Subramanian, 1983; Chlebicki, 1995; Robinson, 2001; Sucharzewska, 2009, 2010; Braga et al., 2015; Zafra et al., 2015; Zalewska et al., 2015).

The mean number of fruitbodies developed by E. platani per $1 \mathrm{~cm}^{2}$ of the host's leaf surface was higher at locality B in all the study years. Locality B is situated near busy traffic routes and locality $\mathrm{C}$ is situated in park conditions (Table 4). In the first year of infection on leaves derived from localities B and C, young fruitbodies, with unpigmented walls, were the most numerous group while fully developed teleomorphs (with fully developed appendages) were observed only at locality B. In the second and subsequent years of the disease, fully developed teleomorphs occurred at both localities; however, the highest percentage was detected for not fully developed fruitbodies (a lighter wall than in fruitbodies in the final stage of development, partially developed appendages). In studies into the expansion of E. platani in Europe, only

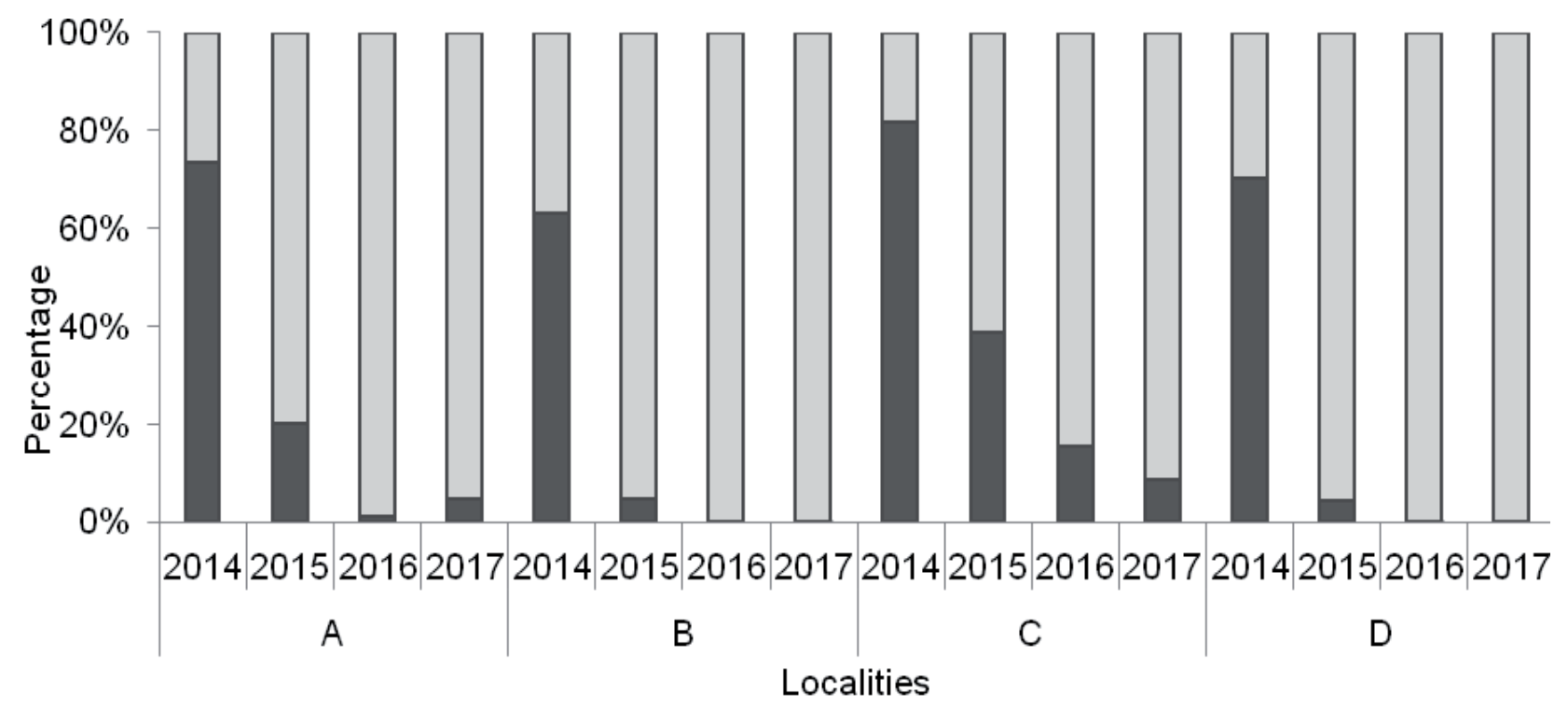

-Anamorphic stage $\square$ Anamorphic and teleomorphic stages

Figure 2. The percentage contribution of samples with E. platani in various developmental stages 
Table 3. Phenology of E. platani in the years 2014-2017

\begin{tabular}{|c|c|c|c|c|c|c|c|c|c|c|c|c|c|c|c|c|}
\hline \multirow{3}{*}{ Season } & \multicolumn{16}{|c|}{ Locality } \\
\hline & \multicolumn{4}{|c|}{$\mathbf{A}$} & \multicolumn{4}{|c|}{ B } & \multicolumn{4}{|c|}{$\mathbf{C}$} & \multicolumn{4}{|c|}{ D } \\
\hline & 2014 & 2015 & 2016 & 2017 & 2014 & 2015 & 2016 & 2017 & 2014 & 2015 & 2016 & 2017 & 2014 & 2015 & 2016 & 2017 \\
\hline \multicolumn{17}{|l|}{$15 . \mathrm{VI}$} \\
\hline $30 . \mathrm{VI}$ & & & O & O & O & & O & O & & & O & O & & & O & O \\
\hline 15.VII & & & O & 0 & O & & O & O & & & $\bigcirc$ & $\bigcirc$ & & & O & O \\
\hline 31.VII & & & 0 & O & 0 & O & 0 & O & & & O & O & & & O & O \\
\hline 15.VIII & ○ & & O & 0 & ○ & 0 & O & 0 & $\bigcirc$ & & O & $\bigcirc$ & $\bigcirc$ & & O & 0 \\
\hline 31.VIII & 0 & ○ & O & ○ & $\bigcirc \bullet$ & O & 0 & O & ○ & O & O & O & O & O & O & O \\
\hline 15.IX & O & O & O & 0 & 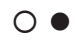 & 0 & $\bigcirc \bullet$ & $\bigcirc \bullet$ & $\bigcirc$ & ○ & $\bigcirc$ & O & O & O & $\bigcirc$ & O \\
\hline 30.IX & O & O & O & ○ & $\circ \bullet$ & $\bigcirc$ & $\circ \bullet$ & $\bigcirc \bullet$ & O & ○ & $\mathrm{O} \bullet$ & $\bigcirc \bullet$ & O & O & $\circ \bullet$ & $\bigcirc \bullet$ \\
\hline 15.X & $\circ \bullet$ & $\mathrm{O} \bullet$ & $\bigcirc \bullet$ & $\mathrm{O} \bullet$ & $\circ \bullet$ & $\circ \bullet$ & $\circ \bullet$ & $\bigcirc \bullet$ & $\circ \bullet$ & $\circ \bullet$ & $\mathrm{O} \bullet$ & $\mathrm{O} \bullet$ & $\bigcirc \bullet$ & $\circ \bullet$ & $\circ \bullet$ & $\mathrm{O}^{\circ}$ \\
\hline 31.X & $\mathrm{O} \bullet$ & $\mathrm{O} \bullet$ & $\circ \bullet$ & $\circ \bullet$ & $\circ \bullet$ & $\circ \bullet$ & $\bigcirc \bullet$ & $\mathrm{O} \bullet$ & $\mathrm{O} \bullet$ & $\circ \bullet$ & $\mathrm{O} \bullet$ & $\mathrm{O} \bullet$ & $\bigcirc \bullet$ & $\circ \bullet$ & $\circ \bullet$ & $0^{\circ}$ \\
\hline
\end{tabular}

$\bigcirc$ - anamorphic stage (Oidium spp.); - teleomorphic stage (fruitbodies, chasmothecia)

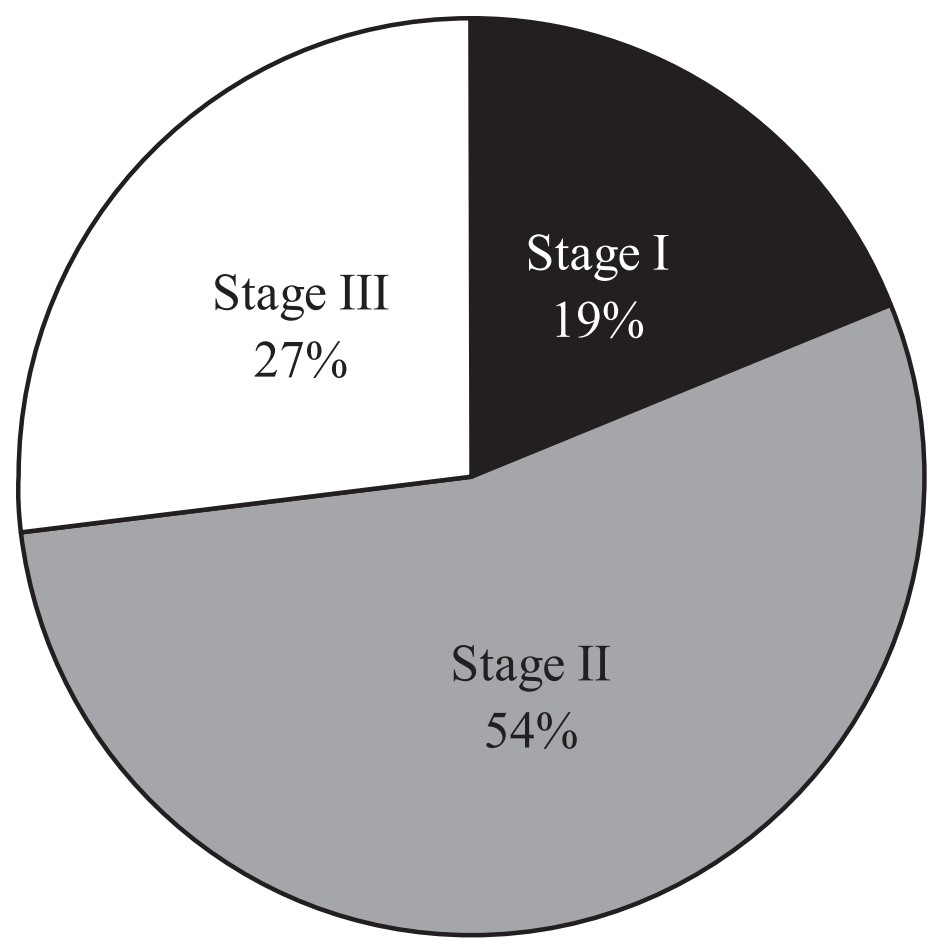

Figure 3. The percentage contribution of chasmothecia of E. platani in various developmental stages (I - unpigmented fruitbodies (with hyaline or straw-coloured walls), without appendages; II - fruitbodies with light-brown walls, at the initial stage of appendage formation; III - fruitbodies with brown walls, with fully developed appendages) 
the presence of the anamorphic stage, often additionally parasitized by fungi of the genus Ampelomyces, was noted in the first years of the infection (Pastirčáková et al., 2014). The teleomorphic stage of E. plantain was first observed in Europe in 2003 (Ranković, 2003). In the present study, the teleomorphic stage was formed as early as in the first year of infection.
The occurrence of a fungus belonging to the genus Ampelomyces was noted only in the structures of E. platani at locality B collected in 2017 (inside spores of the anamorphic stage Oidium spp. and E. platani fruitbodies). Teleomorphs colonized by the hyperparasite had a palebrown wall and short, undeveloped appendages within which Ampelomyces spp. spores formed. Anamorphic

Table 4. The mean number of chasmothecia of E. platani per $1 \mathrm{~cm}^{2}$ of leaves in particular years of the study (significantly at significance level: $\alpha=0.05 ; F(3.12)=47.17 ; p<0.05)$

\begin{tabular}{|c|c|c|c|c|c|}
\hline \multirow{2}{*}{ Locality } & \multicolumn{4}{|c|}{ Year of study } & \multirow{2}{*}{ Mean } \\
\hline & 2014 & 2015 & 2016 & 2017 & \\
\hline & \multicolumn{4}{|c|}{ Number of chasmothecia per $1 \mathrm{~cm}^{2}$} & \\
\hline A & 0.6 & 3.9 & 6.5 & 5.7 & 4.17 \\
\hline B & 0.7 & 4.2 & 6.9 & 6.1 & 4.47 \\
\hline $\mathrm{C}$ & 0.3 & 1.9 & 4.8 & 5.2 & 3.05 \\
\hline $\mathrm{D}$ & 0.7 & 4.0 & 6.6 & 5.9 & 4.3 \\
\hline Mean & 0.57 & 3.5 & 6.2 & 5.72 & \\
\hline
\end{tabular}

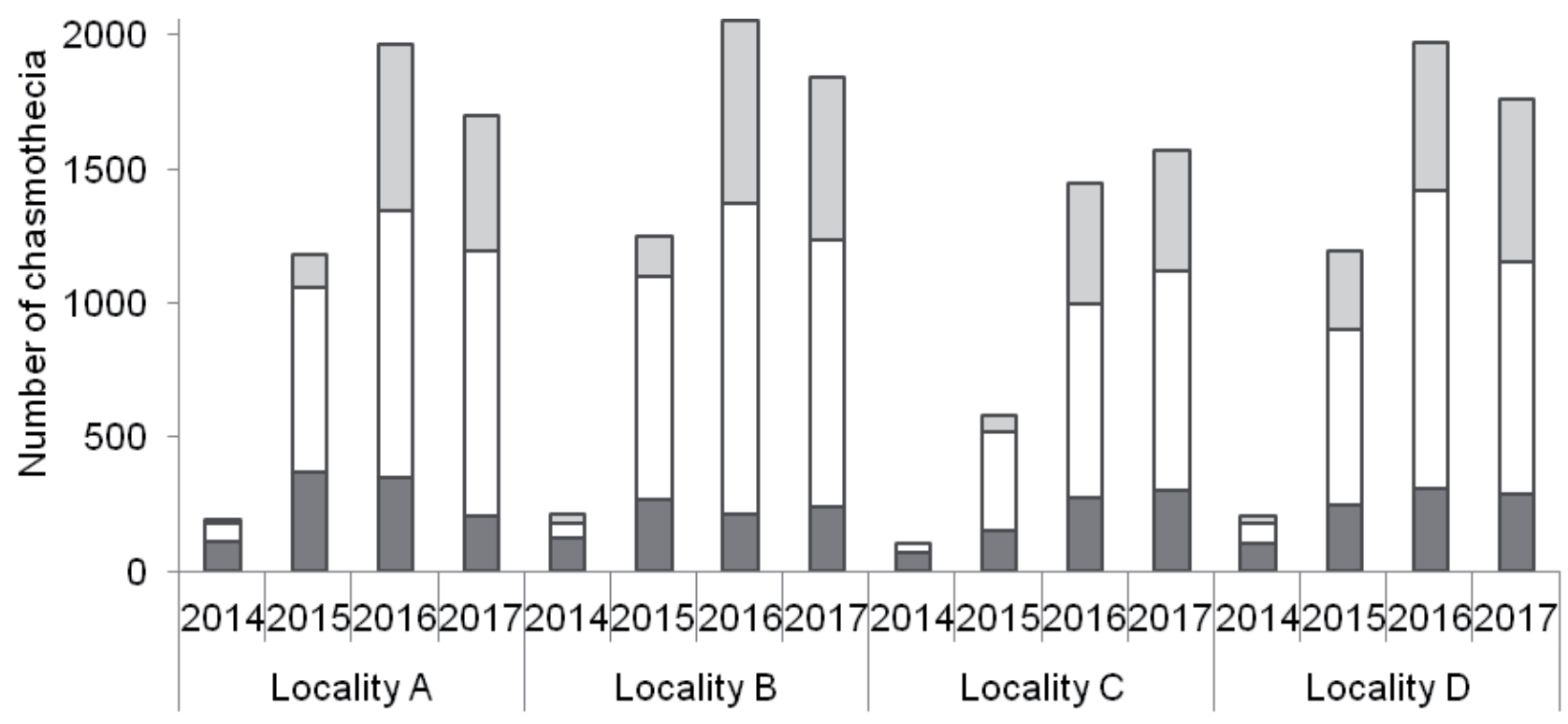

Year of study

$\square$ Stage I $\square$ Stage II $\square$ Stage III

Figure 4. The number of chasmothecia of E. platani in various developmental stages in the particular years of the study (I - teleomorphs, with unpigmented walls, without appendages; II - teleomorphs with light-brown walls, with partly developed appendages; III - fully developed teleomorphs) 
Table 5. The abundance of chasmothecia in individual infection years - Scheffe test (MS between groups $0.55958 ; d f 12)$ and differences between average values (numbers on gray background)

\begin{tabular}{|c|c|c|c|c|}
\hline \multirow{2}{*}{ Year } & \multicolumn{4}{|c|}{ Year of study } \\
\cline { 2 - 5 } & $\mathbf{2 0 1 4}$ & $\mathbf{2 0 1 5}$ & $\mathbf{2 0 1 6}$ & $\mathbf{2 0 1 7}$ \\
\hline 2014 & - & 0.001280 & 0.000002 & 0.000006 \\
\hline 2015 & 2.925 & - & 0.002462 & 0.010320 \\
\hline 2016 & 5.625 & 2.700 & - & $0.846661 *$ \\
\hline 2017 & 5.150 & 2.225 & 0.475 & - \\
\hline
\end{tabular}

*not significantly (significance level $\alpha=0.05$ )

spores degenerated as a result of the hyperparasite, losing their ability to germinate. This influence of the hyperparasite on different fungal species of the order Erysiphales has been observed in the literature (Hashioka \& Nakai, 1980; Sundheim, 1982; Sundheim \& Krekling, 1982; Sztejnberg et al., 1989; Kiss, 1998; Szentiványi \& Kiss, 2003; Kiss et al., 2004; Kiss, 2008; Sucharzewska et al., 2011; Menge \& Makobe, 2016).

The occurrence of Discula platani Sacc. (the teleomorphic stage of Apiognomonia veneta Sacc. \& Speg.) was noted at all the research localities every year. The fungus colonized both new and older leaves of $P . \mathrm{x}$ hispanica. The fungus, which co-occurred with E. platani, caused a mass dieback of the newest twig fragments in the spring 2015. The frequency of D. platani at individual localities was the highest (100\%; symptoms were noted on all the trees studied at a locality). The fungus is a common pathogen widespread in Europe (Farr \& Rossman, 2016; Mułenko et al., 2008). It mostly causes premature defoliation; a more rapid course of anthracnose is related to specific weather conditions recorded in winter and early spring (Bahnweg et al., 2005; Ivanowa et al., 2007; Sogonov et al., 2007). The occurrence of E. platani intensified anthracnose symptoms in the present study.

\section{Conclusions}

1. The degree of infestation of trees by Erysiphe platani depends on the age of the trees, the age of the leaves and environmental conditions. Younger leaves are more strongly infected than older ones. The fungus has a negative effect on the development of young chestnut trees.

2. Symptoms of the disease caused by Erysiphe platani are greater in the first years of infection and then decreases.
3. The biology of Erysiphe platani depends on the duration of the epidemic. In the first years of the epidemic fungus forms fewer fruiting bodies and they mature more slowly than in the later years of the epidemic.

4. Occurrence Erysiphe platani on the leaves of horse chestnut trees intensifies the symptoms of anthracnose caused by Discula platani.

\section{References}

Bahnweg G., Heller W., Stich S., Knappe C., Betz G., Heerdt C., Kehr R.D., Ernst D., Langebartels C., Nunn A.J., Rothenburger J., Schubert R., Wallis P., MüllerStarck G., Werner H., Matyssek R. \& Sandermann H., 2005, Beech leaf colonization by the endophyte Apiognomonia errabunda dramatically depends on light exposure and climatic conditions. Plant Biol. 7: 659-669.

Beenken L., 2017, First records of the powdery mildews Erysiphe platani and E. alphitoides on Ailanthus altissima reveal host jumps independent of host phylogeny. Mycological Progress 16(2): 135-143.

Bonde M.R., Nester S.E. \& Berner D.K., 2012, Effects of Soybean Leaf and Plant Age on Susceptibility to Initiation on Infection by Phakopsora pachyrhizi. Plant Health Prog. (doi:10.1094/PHP-2012-0227-01RS).

Boyd L., Ridout C., O’Sullivan D.M., Leach J.E. \& Leung H. 2013, Plant-pathogen interactions: disease resistance in modern agriculture. Trends in Genetics 29(4): 233-240.

Braga G.U.L., Rangel D.E.N., Fernandes E.K.K., Flint S.D. \& Roberts D.W., 2015, Molecular and physiological effects of environmental UV radiation on fungal conidia. Current Genetics 61(3). (https:// doi.10.1007/s00294-015-0483-0). 
Calo L., Garcia I., Gotor C. \& Romero L.C., 2006, Leaf hairs influence phytopathogenic fungus infection and confer an increased resistance when expressing a Trichoderma a-1,3-glucanase. J. Exp. Bot. 57(14): 3911-3920.

Carpenter R.J., Hill R.S. \& Jordan G.J., 2005, Leaf cuticular morphology links Platanaceae and Proteaceae. International Journal of Plant Sciences 166(5): 843-855.

Chlebicki A., 1995, Microfungi on Dryas extracted from Polish phanerogram herbaria. Acta Soc. Bot. Pol. 64(4): 393-407.

Czerniawska-Kusza I., Kusza G. \& Dużyński M., 2004, Effect of deicing salts on urban soils and health status of roadside trees in the Opole region. Environ Toxicol.19(4): 296-301. (doi: 10.1002/tox.20037).

Develey-Rivière M.-P. \& Galiana E., 2007, Resistance to pathogens and host developmental stage: a multifaceted relationship within the plant kingdom. New Phytol. 175: 405-416. (doi: 10.1111/j.14698137.2007.02130.x).

Dineva S.B., 2004, Comparative studies of the leaf morphology and structure of white ash Fraxinus americana L. and London plane tree Platanus acerifolia Willd growing in polluted area. Dendrobiology 52: 3-8.

Dmuchowski W., Baczewska A.H., Gozdowski D. \& Brągoszewska P., 2013, Effect of salt stress on the chemical composition of leaves of different tree species in urban environment. Fresen Environ Bull 22(4): 987-994.

Dmuchowski W., Baczewska A.H., Gozdowski D., Rutkowska B., Szulc W., Suwara I. \& Brągoszewska P., 2014, Effect of salt stress caused by deicing on the content of microelements in leaves of linden. Journal of Elementology 19(1): 65-79. (doi: 10.5601/ jelem.2014.19.1.588).

Dynowska M., 1994, A comparison of urban and suburban occurrence of Erysiphales with special emphasis on degree of host infection. Acta Soc. Bot. Pol. 63: 341344.

Dynowska M., 1996, Attempt at application of Microsphaera alphitoides Griff. et Maubl. in bioindication. Phytopathologia Polonica 11: 93-96.

Dynowska M. \& Sucharzewska E., 2005, Differentiated reactions of fungi of the order Erysiphales in urban areas, monophagous and polyphagous species. Acta Mycol. 40: 259-265.

Farr D.F. \& Rossman A.Y., 2016, Fungal Databases, Systematic Mycology and Microbiology Laboratory ARS, USDA. (Retrieved June 20, 2016, from http:// nt.ars-grin.gov/fungaldatabases/).

Geagea L., Huber L., Sache I., Flura D., McCartney H.A. \& Fitt B.D.L., 2000, Influence of simulated rain dispersal of rust spores from infected wheat seedlings. Agricultural and Forestry Meteorology 101(1): 53-66.
Grote R., Samson R., Alonso R., Amorim J.H., Cariñanos P., Churkina G., Fares S., Le Thiec D., Niinemets U., Mikkelsen T.N., Paoletti E., Tiwary A. \& Calfapietra C., 2016, Functional traits of urban trees: air pollution mitigation potential. Frontiers in Ecology and the Environment 14(10): 543-550. (https://doi:10.1002/ fee.1426).

Hashioka Y. \& Nakai Y., 1980, Ultrastructure of pycnidial development and mycoparasitism of Ampelomyces quisqualis parasitic on Erysiphales. Trasn. Mycol. Soc. Japan 21: 329-338.

Heluta V.P., Korytnianska V.G. \& Akata I., 2013, Distribution of Erysiphe platani (Erysiphales) in Ukraine, Acta Mycol. 48(1): 105-112. (doi: 10.5586/ am.2013.012).

Ivanowa I., Bernadovičiova S. \& Pastirčakova K., 2007, Influence of changed ecological conditions on occurrence of London plane (Platanus x hispanica Münchh.) anthracnose. Folia Oecol. 34(1): 1-8.

Kirschner R., 2011, Observations on Erysiphe platani in Germany. Plant Pathology \& Quarantine 1(2): 115-119.

Kiss L., 1998, Natural occurrence of Ampelomyces intracellular mycoparasites in mycelia of powdery mildew fungi. New Phytol. 140: 709-714.

Kiss L., 2008, Intracellular mycoparasites in action: Interactions between powdery mildew fungi and Ampelomyces. Stress in Yeast and Filamentous Fungi. British Mycological Society Symposia Series 27: 37-52.

Kiss L., Russell J., Szentiványi O., Xu X. \& Jeffries P., 2004, Biology and biocontrol potential of Ampelomyces mycoparasites, natural antagonists of powdery mildew fungi. Biocontrol Science and Technology 14(7): 635-651.

Levia D.F., Hudson S.A., Llorens P. \& Nanko K., 2017, Throughfall drop size distributions: a review and prospectus for future research. WIREs Water 4: e1225. (doi: 10.1002/wat2.1225).

Ligoxigakis E.K., Markakis E.A., Papaioannou I.A. \& Typas M.A., 2015, First Report of Powdery Mildew of Platanus $\times$ acerifolia and P. occidentalis Caused by Erysiphe platani in Greece. Plant Disease 99(2): 286. (http://dx.doi.org/10.1094/PDIS-07-14-0713-PDN).

Lindow S.E. \& Brandl M.T., 2003, Microbiology of the phyllosphere. Appl. Environ. Microbiol. 69: 1875-1883. Machowicz-Stefaniak Z. \& Zalewska E., 2009, Fungi colonizing various parts of parsnip Pastinaca sativa L. Herba Polonica 55(2): 7-17.

McEvoy A., O’Regan F., Fleming C.C., Moreland B.P., Pollock J.A., McGuinness B.W. \& Hodkinson T.R., 2016, Bleeding canker of horse chestnut (Aesculus hippocastanum) in Ireland: incidence, severity and characterization using DNA sequences and real- 
time PCR. Plant Pathology 65(9): 1419-1429. (doi: 10.1111/ppa.12529).

Menge D. \& Makobe M., 2016, Biological control of cashew powdery mildew using Ampelomyces quisqualis Ces. Journal of Biological Control 30(4): 226-235. (doi: 10.18311/jbc/2016/15591).

Mimet A., Pellissier V., Quénol H., Aguejdad R., Dubreuil V. \& Rozé F., 2009, Urbanisation induces early flowering: evidence from Platanus acerifolia and Prunus cerasus. Int. J. Biometeorol. 53: 287-298.

Mułenko W., Majewski T. \& Ruszkiewicz-Michalska M., 2008, A preliminary checklist of micromycetes in Poland. W. Szafer Institute of Botany, Polish Academy of Sciences, Kraków, 752 pp.

Newbound M., Mccarthy M.A. \& Lebel T., 2010, Fungi and the urban environment: A review. Landscape and Urban Planning 9: 138-145.

Oleksyn J., Kloeppel B.D., Łukasiewicz S., Karolewski P. \& Reich P.B., 2007, Ecophysiology of horse chestnut (Aesculus hippocastanum L.) in degraded and restored urban sites. Pol. J. Ecol. 55 (2): 245-260.

Pastirčáková K. \& Pastirčák M., 2006, The anamorph of Erysiphe platani on Platanus x hispanica in Slovakia. Mycotaxon 97: 189-194.

Pastirčáková K. \& Pastirčák M., 2008, Erysiphe platani causing powdery mildew of London plane in Hungary. Acta Phytopathol. Entomol. Hung. 43(1): 31-36. (doi: 10.1556/APhyt.43.2008.1.4).

Pastirčáková K., Pastirčák M., Adamčiková K., Bouznad Z., Kedad A., El Guilli M., Diminić D. \& Hofte M., 2014, Global distribution of Erysiphe platani: new records, teleomorph formation and re-examination of herbarium collections. Cryptogamie, Mycologie 35(2): 163-176. (doi: http://dx.doi.org/10.7872/crym. v35.iss2.2014.163).

Ranković B., 2003, Powdery mildew fungi (order Erysiphales) on plants in Montenegro (Chernogoria). Mikologyia i Fitopatologyia 37: 42-52.

Robinson C.H., 2001, Cold adaptation in Arctic and Antarctic fungi. New Phytologist 151: 341-353.

Salazar S.M., Castagnaro A.P., Arias M.E., Chalfoun N., Tonello U. \& Diaz Ricci J.C., 2007, Introduction of a defense response in strawberry mediated by an avirulent strain of Colletotrichum. Eur. J. Plant Pathol. 117: 109-122.

Santamour F.S. \& McArdle A.J., 1986, Checklist of cultivated Platanus (plane tree). Journal of Arboriculture 12: 78-83.

Scholler M., Hemm V. \& Lutz M., 2012, Erysiphe platani: monitoring of an epidemic spread in Germany and molecular characterization based on rDNA sequence data. Andrias 19: 263-272.
Singh R. \& Chandrawat K.S., 2017, Role of Phytoalexins in Plant Disease Resistance. Int. J. Curr. Microbiol. App. Sci. 6(1): 125-129. (http://dx.doi.org/10.20546/ ijcmas.2017.601.016).

Sogonov M.V., Castlebury L.A., Rossman A.Y. \& White J.F., 2007, The type species of Apiognomonia, $A$. veneta, with its Discula anamorph is distinct from A. errabunda. Mycol. Res. 3: 693-709.

Subramanian C.V., 1983, Hyphomycetes. Taxonomy and Biology. Academic Press. Inc., London, 502 pp.

Sucharzewska E., 2009, The development of Erysiphe alphitoides i E. hypophylla in the urban environment. Acta Mycol. 44(1): 109-123.

Sucharzewska E., 2010, Key survival strategies of the Sawadaea tulasnei parasite on its Acer platanoides host under conditions of varied anthropopression. Polish J Environ. Stud. 19(5): 1013-1017.

Sucharzewska E. \& Dynowska M., 2005, Life strategies of Erysiphe palczewskii in the conditions of diversified anthropopressure. Acta Mycol. 40: 103-112.

Sucharzewska E., Dynowska M., Ejdys E., Biedunkiewicz A. \& Kubiak D., 2012, Hyperparasites of Erysiphales fungi in the urban environment. Pol. J. Natur. Sci. 27(3): 289-299.

Sucharzewska E., Dynowska M. \& Kempa A.B., 2011, Occurrence of the fungi from the genus Ampelomyces hyperparasites of powdery mildews (Erysiphales) infesting trees and bushes in the municipal environment. Acta Soc. Bot. Pol. 80(2): 169-174.

Sundheim L., 1982, Control of cucumber powdery mildew by the hyperparasite Ampelomyces quisqualis and fungicides. Plant Pathology 31: 209-214.

Sundheim L. \& Krekling T., 1982, Host-parasite relationships of the hyperparasite Ampelomyces quisqualis and its powdery mildew host Sphaerotheca fuliginea. J Phytopathol. 104: 202-210.

Surendra A. \& Cuperlovic-Culf M., 2017, Database of resistance related metabolites in Wheat Fusarium head blight Disease (MWFD). Database 2017: article ID bax076. (doi:10.1093/database/bax076).

Szentiványi O. \& Kiss L., 2003, Overwintering of Ampelomyces mycoparasites on apple trees and other plants infected with powdery mildews. Plant Pathology 52: 737-746.

Sztejnberg A., Galper S., Mazar S. \& Lisker N., 1989, Ampelomyces quisqualis for biological and integrated control of powdery mildews in Israel. J. Phytopathol. 124: 285-295.

Xiao K., Mao K., Lin Y., Xu H., Zhu Y., Cai Q., Xie H. \& Zhang J., 2017, Trichome, a Functional Diversity Phenotype in Plant. Mol. Biol. 6: 183 (doi: 10.4172/2168-9547.1000183). 
Yang J., Chang Y.M. \& Yan P.B., 2015, Ranking the suitability of common urban tree species for controlling M2.5 pollution. Atmospheric Pollution Research 6: 267-277. (doi:10.5094/apr.2015.031).

Zafra G., Absalón A.E. \& Cortés-Espinosa D.V., 2015, Morphological changes and growth of filamentous fungi in the presence of high concentrations of PAHs. Braz. J. Microbiol. 46(3): 937-941. (doi: http://dx.doi. org/10.1590/S1517-8382463201405).
Zalewska E.D., Machowicz-Stefaniak Z. \& Król E.D., 2015, Fungi colonizing caraway (Carum carvi L.) in different regions of cultivation. Acta Sci. Pol. Hortorum Cultus 14(6): 175-188.

Zimmermannová-Pastirčáková K., Adamska I., Błaszkowski J., Bolay A. \& Braun U., 2002, Epidemic spread of Erysiphe flexuosa (North American powdery mildew of horse-chestnut) in Europe. Schlechtendalia 8: 39-45. 